\title{
Electrodialytic extraction of heavy metals from Greenlandic MSWI fly ash as a function of remediation time and $\mathrm{L} / \mathrm{S}$ ratio
}

\author{
Kirkelund, Gunvor Marie; Jensen, Pernille Erland; Ottosen, Lisbeth M.
}

Published in:

ISCORD 2013 : Planning for Sustainable Cold Regions

Publication date:

2013

Document Version

Publisher's PDF, also known as Version of record

Link back to DTU Orbit

Citation $(A P A)$ :

Kirkelund, G. M., Jensen, P. E., \& Ottosen, L. M. (2013). Electrodialytic extraction of heavy metals from Greenlandic MSWI fly ash as a function of remediation time and L/S ratio. In ISCORD 2013 : Planning for Sustainable Cold Regions (pp. 87-96). American Society of Civil Engineers.

\section{General rights}

Copyright and moral rights for the publications made accessible in the public portal are retained by the authors and/or other copyright owners and it is a condition of accessing publications that users recognise and abide by the legal requirements associated with these rights.

- Users may download and print one copy of any publication from the public portal for the purpose of private study or research.

- You may not further distribute the material or use it for any profit-making activity or commercial gain

- You may freely distribute the URL identifying the publication in the public portal 


\title{
Electrodialytic Extraction of Heavy Metals from Greenlandic MSWI Fly Ash as a Function of Remediation Time and L/S ratio
}

\author{
Gunvor M. Kirkelund, PhD, Pernille E. Jensen, $\mathrm{PhD}$ \\ Arctic Technology Centre, Department of Civil Engineering, Technical University of Denmark, Lyngby, \\ Denmark \\ Lisbeth M. Ottosen, $\mathrm{PhD}$ \\ Department of Civil Engineering, Technical University of Denmark, Lyngby, Denmark
}

\begin{abstract}
The management of Greenlandic municipal solid waste incineration (MSWI) fly ash could be improved. Presently, the fly ash is disposed of in Norway as the fly ash is classified as hazardous waste. Fly ash contains high amounts of leachable heavy metals, but also resources that could be beneficial for reuse. In electrodialytic remediation a direct current is applied to a contaminated particulate material to remove heavy metals from the material. In this study, electrodialytic remediation was applied to a Greenlandic MSWI fly ash from a small waste incinerator in Ilulissat. The fly ash was characterized before and after the electrodialytic remediation experiments for heavy metals content, amount of soluble heavy metals and $\mathrm{pH}$. Before the electrodialytic experiments the water solubility of $\mathrm{Ba}, \mathrm{Cr}$ and $\mathrm{Pb}$ was high from the alkaline fly ash. Six electrodialytic remediation experiments were made, where the fly ash was suspended in distilled water in different liquid to solid (L/S) ratios. Remediation times of 7 and 14 days were tested and the current strength was $50 \mathrm{~mA}$ in all experiments. The highest removal was seen when an acidic $\mathrm{pH}$ in the fly ash suspension was obtained. In an experiment lasting 14 days with L/S 10, up to $60 \% \mathrm{Cd}, 45 \% \mathrm{Zn}, 20 \% \mathrm{Ni}$ and $\mathrm{Ba}$ was removed. Regardless of the remediation time and $\mathrm{L} / \mathrm{S}$ ratio, the fraction of soluble $\mathrm{Ba}, \mathrm{Cr}$ and $\mathrm{Pb}$ decreased due to the electrodialytic remediation. The electrodialytic remediation method showed potential as a treatment method for the Greenlandic fly ash.
\end{abstract}

KEY WORDS: Electrokinetic remediation, waste incineration, fly ash, heavy metals, Arctic

\section{INTRODUCTION}

In Greenland, waste has traditionally been dumped at open disposal sites combined with uncontrolled incineration. In the mid 1990'es, the first waste strategy was implemented in Greenland. As a result municipal solid waste incineration (MSWI) plants were introduced in the 2000s in the six largest Greenlandic towns: Nuuk, Sisimiut, Ilulissat, Aasiaat, Maniitsoq and Qaqortoq. The incinerators should primarily minimize the amount of waste at the disposal sites, but also introduced heat recovery for the district heating systems. The plants are smaller and simpler than traditional European waste incinerators and have a capacity between 2,000 - 10,000 tons annually (Eisted and Christensen, 2011), which in contrast is a typical daily capacity in larger European incinerators. Mainly household waste is incinerated, whereas incombustible waste is disposed of at the 
uncontrolled disposal sites, and hazardous waste and reusable metal is stored at the disposal sites before being shipped to Denmark for further treatment. Separation of household waste is very limited. Fly ash, bottom ash and flue gas are the resulting residues from MSWI, which contain the inorganic content of the incinerated waste in concentrated form, and especially fly ash is highly toxic.

The Greenlandic MSWI plants have simple flue gas treatment, removing fly ash particles by a cyclone and/or an electrostatic precipitator. MSWI fly ash is highly toxic due to the content of toxic elements and salts and their leaching behavior. Therefore, disposal of fly ash directly on the uncontrolled Greenlandic disposal sites is prohibited. Up to 900 tons of toxic MSWI fly ash is every year deposited in Norway, since no Greenlandic disposal sites are safe for disposal of this hazardous material.

Apart from being potentially toxic, the MSWI residues also contain resources and valuable elements that could be reused. Previously, bottom ash from Greenlandic waste incinerators has shown potential for reuse as subbase material in roads (Kirkelund et al., 2012). Fly ash could also be reused but requires pre-treatment to lower the toxicity (Quina et al., 2008), and until now no treatment method has been politically accepted for treating the hazardous fly ash. If the Greenlandic fly ash could be treated it would contribute to solving the expensive problem of disposal abroad. A way to lower the toxicity of the fly ash is to remove heavy metals. This could be done by electrodialytic remediation. A sketch of the electrodialytic remediation laboratory set-up is shown in Figure 1.

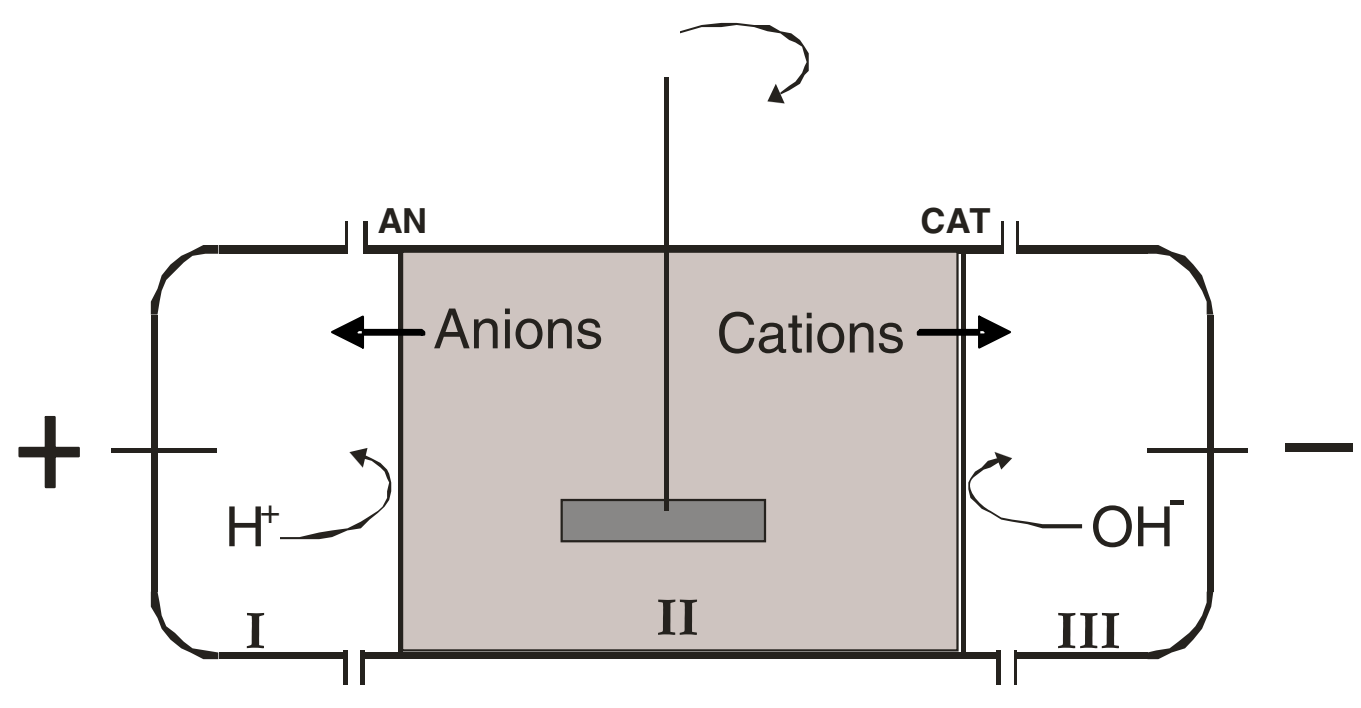

Figure 1: The electrodialytic laboratory cell. AN - anion exchange membrane, CAT cation exchange membrane.

In electrodialytic remediation, an electric DC field is applied to a fly ash suspension (compartment II) and heavy metals are released as ions from the fly ash by both 
dissolution and an acidification process. The released metal ions are transported out of the fly ash suspension towards the electrode of opposite charge and concentrated in the electrolytes (compartments I and III). The fly ash suspension compartment is separated from the electrolyte compartments by ion-exchange membranes, which ensure that the main ion transport occurs out of the fly ash suspension. During the electrodialytic remediation process, the fly ash suspension becomes acidified (Ottosen et al., 2000, Pedersen et al., 2005, Nystroem et al., 2005). The acidification is mainly induced by water-splitting at the anion exchange membrane (Ottosen et al., 2000), although some of the acid may also originate from the anolyte, since anion exchange membranes are not $100 \%$ ideal. Further, cation exchange can occur over the cation exchange membrane where $\mathrm{H}^{+}$ions from the catholyte can exchange with other ions from the concentration compartment. The acidification process is usually advantageous since most heavy metals are mobilized at low $\mathrm{pH}$.

The aim of this study was to evaluate if electrodialytic remediation can be used to remove metals ( $\mathrm{Al}, \mathrm{As}, \mathrm{Ba}, \mathrm{Cd}, \mathrm{Cr}, \mathrm{Cu}, \mathrm{Mn}, \mathrm{Ni}, \mathrm{Pb}$ and $\mathrm{Zn}$ ) from Greenlandic fly ash, and to evaluate the remediation efficiency and metal solubility before and after remediation.

\section{MATERIALS AND METHODS}

\subsection{Experimental Fly Ash}

Fly ash from the MSWI incineration plant in Ilulissat, Greenland was used in this study. The incineration temperature is $850{ }^{\circ} \mathrm{C}$ and the incineration plant runs on weekdays. The fly ash was collected after treatment of flue gas in electrostatic filters and kept at room temperature in a sealed container until use. Approximately 3,000 tons of waste is incinerated annually in Ilulissat, which leads to a fly ash production of about 30 tons annually (Gunnarsdottir et al., 2008, Eisted and Christensen, 2011).

\subsection{Analytical Methods}

Heavy metal concentrations (As, $\mathrm{Ba}, \mathrm{Cd}, \mathrm{Cr}, \mathrm{Cu}, \mathrm{Mn}, \mathrm{Ni}, \mathrm{Pb}, \mathrm{Zn}$ ) in the fly ash were measured by ICP-OES (induced couples plasma - optical emission spectrometry) after pre-treatment by Danish Standard DS259 (Dansk Standardiseringsråd, 2003), where $1 \mathrm{~g}$ of fly ash and $20 \mathrm{ml} 7.3 \mathrm{M} \mathrm{HNO}_{3}$ were heated at $200 \mathrm{kPa}\left(120^{\circ} \mathrm{C}\right)$ for $30 \mathrm{~min}$. The liquid was thereafter separated by vacuum filtration through a $45 \mu \mathrm{m}$ filter and diluted to 100 $\mathrm{ml}$. The digestions were made in triplicates. The units used in this paper are $\mathrm{mg} / \mathrm{kg}$ for concentrations in dry matter.

The amount of soluble heavy metals in distilled water was measured by mixing $1 \mathrm{~g}$ fly ash and $40 \mathrm{ml}$ distilled water. The suspensions were shaken for 72 hours on a horizontal shaker operating at $250 \mathrm{rpm}$ and the extractions were made in duplicates. The extractants were filtrated though $45 \mu \mathrm{m}$ and acidified if $\mathrm{pH}>2$ by addition of concentrated $\mathrm{HNO}_{3}$ before measurements of metals by ICP-OES. 
Water content was measured by weight loss at $105^{\circ} \mathrm{C}$ for $24 \mathrm{~h}$. Loss on ignition (LOI) was measured at $550^{\circ} \mathrm{C}$ for one hour. The $\mathrm{pH}$ was measured in $1 \mathrm{M} \mathrm{KCl}$ at a liquid-tosolid ratio (L/S) of 5 and after 1 hour of agitation, by a Radiometer Analytical $\mathrm{pH}$ electrode. The amount of water soluble fly ash was estimated as mass reduction when mixing $1 \mathrm{~g}$ fly ash with $20 \mathrm{ml}$ distilled water, which was agitated for 24 hours.

\subsection{Electrodialytic Experiments}

Six electrodialytic laboratory experiments were made and experimental conditions are seen in Table 1. All experiments were made in room temperature.

Table 1: Experimental conditions for the electrodialytic experiments

\begin{tabular}{l|c|c} 
Experiment & L/S & $\begin{array}{l}\text { Duration } \\
\text { (days) }\end{array}$ \\
\hline 1 & 3.5 & 7 \\
2 & 3.5 & 14 \\
3 & 7 & 7 \\
4 & 7 & 14 \\
5 & 10 & 7 \\
6 & 10 & 14
\end{tabular}

During all experiments a constant current of $50 \mathrm{~mA}$ was applied. The experimental cell is seen in Figure 1. The cell was made of Plexiglas, compartment II was $10 \mathrm{~cm}$ long and had an internal diameter of $8 \mathrm{~cm}$. The electrolyte compartments (I and III) were separated by either cation (CAT) or anion (AN) exchange membranes according to the setup shown in figure 1, to concentrate the removed metals in compartments I and III. The ion exchange membranes were from Ionics (anion exchange membrane 204 SZRA B02249C and cation exchange membrane CR67 HUY N12116B). The electrolytes were $0.01 \mathrm{M}$ $\mathrm{NaNO}_{3}$ adjusted to $\mathrm{pH}<2$ with $1: 1 \mathrm{HNO}_{3}$ and $500 \mathrm{~mL}$ electrolyte circulated in compartments I and III. "Pan World" pumps with a flow rate of $2.6 \mathrm{~L} \mathrm{~min}^{-1}$ were used to circulate the electrolytes. Platinum coated titanium electrodes from Permascand were used as working electrodes and a power supply (Hewlett Packard E3612A) was used to maintain a constant DC current.

The middle compartment (II) contained the fly ash suspension. The suspension consisted of 37.5- $75 \mathrm{~g}$ fly ash and $400 \mathrm{ml}$ distilled water. The fly ash was kept suspended during the experiments by constant stirring with a plastic-flap attached to a glass-stick and connected to an overhead stirrer (RW11basic from IKA). $\mathrm{pH}$ and electrical conductivity were measured in the fly ash suspension daily.

After the electrodialytic experiments, the fly ash suspension was filtered through a $45 \mu \mathrm{m}$ filter and the heavy metal content was measured in the filtered liquid and the fly ash solids. The amount of soluble heavy metal in distilled water was also measured. This analysis could not be made for the fly ash from experiment 6 as there was limited amount of ash after this experiment. The stirrer, membranes and electrodes were rinsed in acid, to 
measure the amount of heavy metals adsorbed onto these. The heavy metal content was also measured in the electrolytes. The electrolytes and the filtered liquid from the middle compartment were preserved by adding concentrated $\mathrm{HNO}_{3}$ in the ratio 1:4 and heated at $200 \mathrm{kPa}\left(120^{\circ} \mathrm{C}\right)$ for $30 \mathrm{~min}$. All the samples were measured by ICP-OES.

\section{RESULTS AND DISCUSSION}

\subsection{Fly ash characteristics}

The results of the fly ash characterization showed a highly alkaline fly ash with various concentrations of metals (Table 2). $\mathrm{Al}, \mathrm{Pb}$ and $\mathrm{Zn}$ were present in the highest concentrations, which is typical for fly ash (Eighmy et al., 1995). The metal content was in the order of: $\mathrm{Al}>\mathrm{Pb}, \mathrm{Zn}>\mathrm{Ba}, \mathrm{Mn}>\mathrm{Cd}, \mathrm{Cr}, \mathrm{Cu}>\mathrm{As}$, Ni. Only $\mathrm{Ba}, \mathrm{Cr}$ and $\mathrm{Pb}$ showed high solubility in water. Thus, the water solubility was not dependent on the total concentration of the metals. $\mathrm{Cr}$ and $\mathrm{Pb}$ are highly toxic metals. Leaching of $\mathrm{Cr}$ in alkaline wastes is typically in the form of $\mathrm{Cr}$ (VI) from chromates, which is highly toxic compared to $\mathrm{Cr}$ (III). Some speciation studies have shown that $\mathrm{Cr}$ is usually in the form of $\mathrm{Cr}$ (III) in fly ashes (Cornelis et al., 2008), but the formation of chromates can happen already at $400{ }^{\circ} \mathrm{C}$ (Billen et al., 2012). The low LOI indicated a complete and efficient combustion during the incineration process, which supports that a high incineration temperature was achieved. Highly soluble $\mathrm{K}_{4} \mathrm{PbO}_{4}$ and $\mathrm{BaCaO}_{2}$, which could also be present, have previously been identified in fly ash (Eighmy et al., 1995), and may be the reason for the water soluble $\mathrm{Pb}$ and $\mathrm{Ba}$ in the studied ash. Also, the result seen here for Pb solubility in water, was a magnitude 10 (in concentration) higher than seen for Danish MSWI fly ash (Ottosen et al., 2006).

Tabel 2 : Fly ash characteristics

\begin{tabular}{l|l} 
Characteristic & Result \\
\hline $\mathrm{LOI}(\%)$ & $0.04 \pm 0.01$ \\
$\mathrm{pH}$ & $12.3 \pm 0.0$ \\
$\mathrm{EC}\left(\mathrm{mS} / \mathrm{cm}^{2}\right)$ & $179.5 \pm 1.9$ \\
$\mathrm{Water} \mathrm{solubility}(\%)$ & $11 \pm 1$ \\
$\mathrm{Al}(\mathrm{mg} / \mathrm{kg}) / \%$ water soluble & $59,700 \pm 5,300 / 0$ \\
$\mathrm{As}(\mathrm{mg} / \mathrm{kg}) / \%$ water soluble & $24.1 \pm 3.4 / 2$ \\
$\mathrm{Ba}(\mathrm{mg} / \mathrm{kg}) / \%$ water soluble & $900 \pm 75 / 10$ \\
$\mathrm{Cd}(\mathrm{mg} / \mathrm{kg}) / \%$ water soluble & $212 \pm 10 / 0.1$ \\
$\mathrm{Cr}(\mathrm{mg} / \mathrm{kg}) / \%$ water soluble & $273 \pm 23 / 29$ \\
$\mathrm{Cu}(\mathrm{mg} / \mathrm{kg}) / \%$ water soluble & $442 \pm 12 / 0.1$ \\
$\mathrm{Mn}(\mathrm{mg} / \mathrm{kg}) / \%$ water soluble & $974 \pm 16 / 0$ \\
$\mathrm{Ni}(\mathrm{mg} / \mathrm{kg}) / \%$ water soluble & $41.2 \pm 10.8 / 1$ \\
$\mathrm{~Pb}(\mathrm{mg} / \mathrm{kg}) / \%$ water soluble & $1,750 \pm 720 / 32$ \\
$\mathrm{Zn}(\mathrm{mg} / \mathrm{kg}) / \%$ water soluble & $12,900 \pm 1,000 / 0.5$
\end{tabular}




\subsection{Electrodialytic remediation experiments}

The $\mathrm{pH}$ and electrical conductivity in the fly ash suspension during the electrodialytic remediation experiments is seen in Figure 2, the metal removal and solubility after the experiments are shown in Figure 3 and 4, respectively. The final $\mathrm{pH}$ in the fly ash and the amount of fly ash recovered after the experiments is shown in Table 3.

The applied current strength of $50 \mathrm{~mA}$ could be maintained in all the experiments and the current strength resulted in voltages between 5-80 V. Higher voltage in some of the experiments could be due to limited amount of ions in the fly ash solution for the carrying the current or membrane fouling (Ottosen et al., 2006).
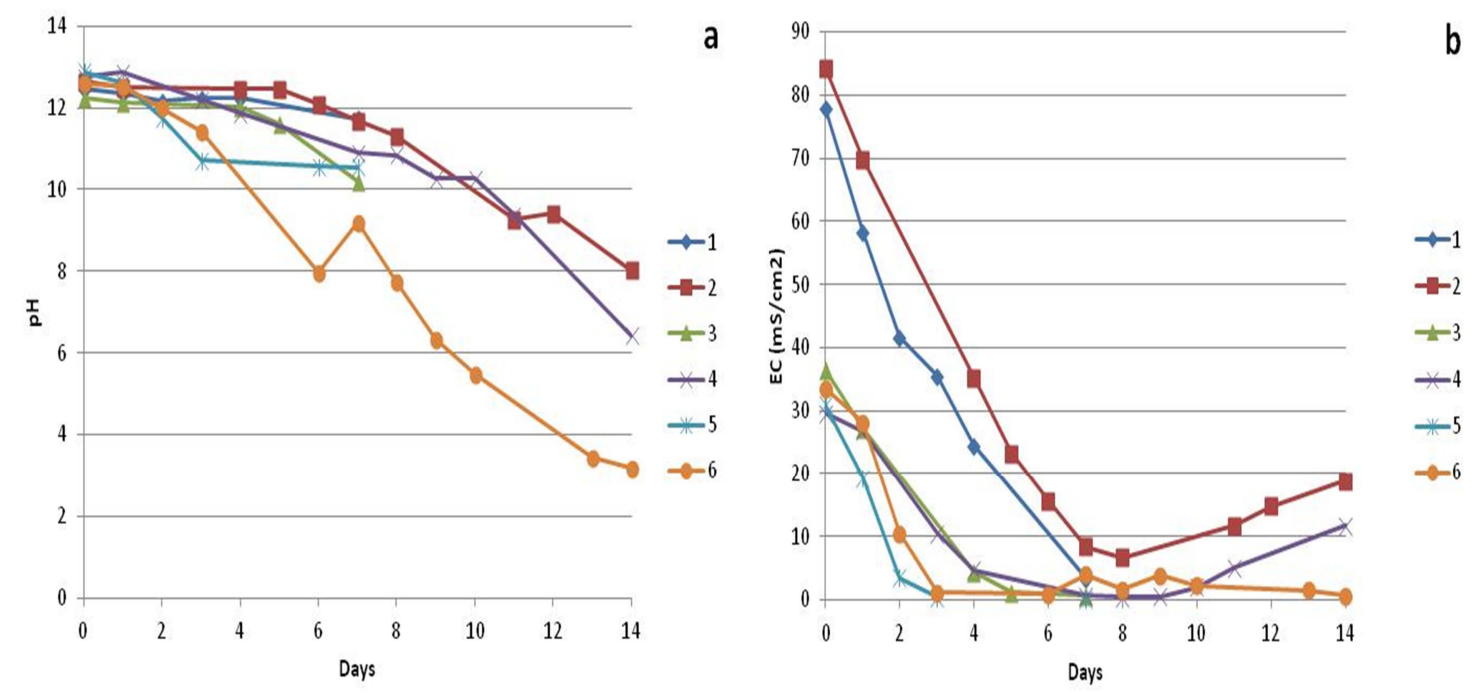

Figure 2: $\mathrm{pH}$ (a) and electrical conductivity (b) in the fly ash suspension during the experiments

The initial $\mathrm{pH}$ in the fly ash suspensions was not dependent on the $\mathrm{L} / \mathrm{S}$ ratio $(\mathrm{pH} 12.5)$. $\mathrm{pH}$ decreased fastest in the fly ash suspension with the lowest amount of fly ash, as could be expected as the buffering capacity should be lower. After 7 days of remediation, $\mathrm{pH}$ was still alkaline $(\mathrm{pH}>10)$ in the fly ash suspension regardless of the L/S ratio. After further 7 days of remediation, $\mathrm{pH}$ was significantly reduced and especially at the highest $\mathrm{L} / \mathrm{S}$ ratio (experiment 6). Due to the acidification a decrease in fly ash mass was seen (table 3 ) and this was also linked to the final $\mathrm{pH}$ in the fly ash. This mass decrease was caused by dissolution of salts and easily soluble minerals.

The initial electrical conductivity was significantly higher in the two experiments with the lowest L/S ratio and the electrical conductivity decreased to similar level in all experiments, indicating that the applied current strength was sufficient for removing the ions in solution. Higher voltage was usually observed at the end of the experiments when the electrical conductivity was low. The ideal remediation time should be when the electrical conductivity is low in the fly ash suspension, as this means that small amounts 
of ions are present. In experiments 2 and 4, with lower L/S ratio than experiment 6 , an increase in the electrical conductivity was seen after 10 days of remediation. At the same time, $\mathrm{pH}$ decreased in the fly ash suspension in these three experiments, which would lead to a higher release of metals and dissolution of solids. This suggests that the applied current density was not sufficient for removing all ions in the experiments with a low L/S ratio after 10 days of remediation.

Table 3: Final pH in fly ash and ash recovery

\begin{tabular}{l|l|l} 
Experiment & Final pH in ash & Ash recovery $(\%)$ \\
\hline 1 & 10.5 & 88 \\
2 & 8.9 & 68 \\
3 & 10.3 & 77 \\
4 & 7.0 & 54 \\
5 & 10.4 & 70 \\
6 & 4.1 & 41
\end{tabular}

The metal removal was defined as the amount of metal found in the electrolytes (I and III), the membranes and electrodes, compared to the total metal amount measured in the cells after remediation.

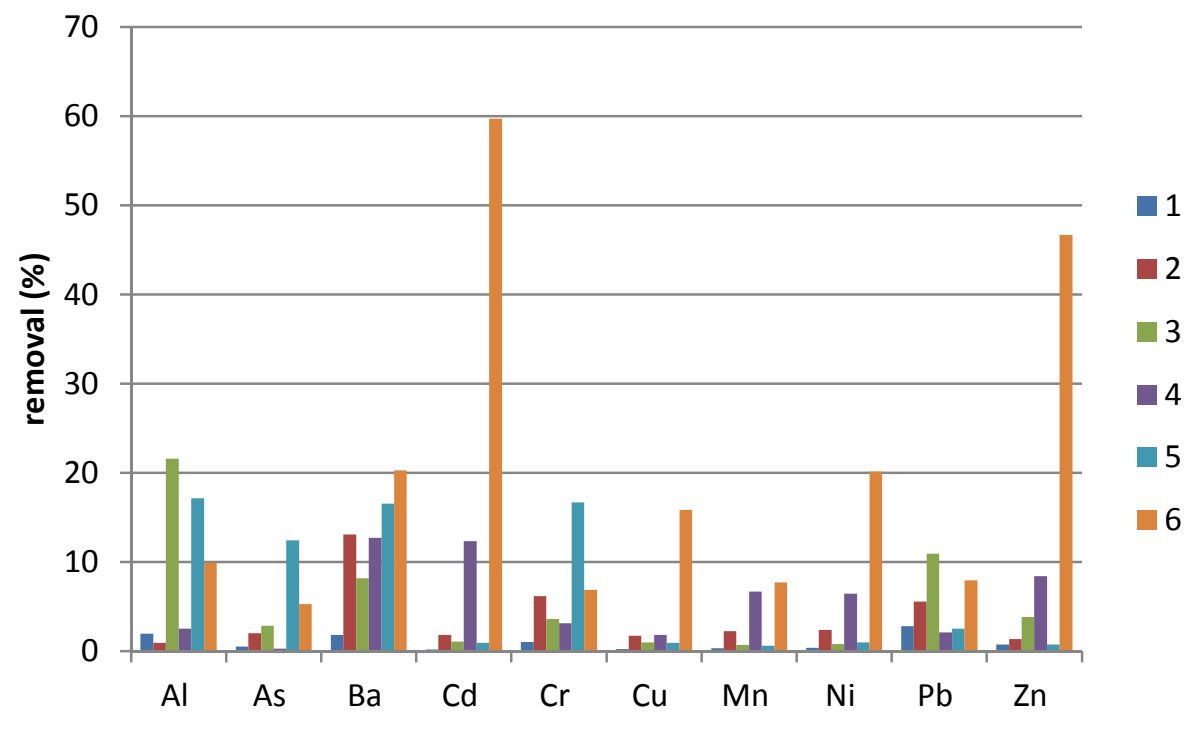

Figure 3: Removal of metals in the electrodialytic remediation experiments

The removal seemed to increase with increasing remediation time and L/S ratio, but no distinct pattern could be seen. The highest removal was in experiment 6 , where the lowest $\mathrm{pH}$ in the fly ash suspension was obtained. In this experiment up to $60 \% \mathrm{Cd}, 45 \% \mathrm{Zn}$, and $20 \% \mathrm{Ni}$ and $\mathrm{Ba}$ was removed. For the other metals up to $15 \%$ was removed. These removal rates differed from the initial water soluble fractions. For instance, $\mathrm{Cd}, \mathrm{Ni}$ and Zn were removed to a much higher extent than what was initially water soluble, which was less than $1 \%$. Thus, the application of the electric current was beneficial for the 
removal. Contrarily, the amount of removed $\mathrm{Cr}$ and $\mathrm{Pb}$ was lower than what could be expected from the water soluble amounts. The L/S ratio in the experiments for water solubility of metals (L/S 40) was much higher than in the actual electrodialytic remediation experiments (L/S $3.5-10)$ and this suggests that the release of $\mathrm{Cr}$ and $\mathrm{Pb}$ was solubility controlled, which was also found by Quina et al. (2011).

In Figure 4, the amount of water soluble $\mathrm{Ba}, \mathrm{Cr}$ and $\mathrm{Pb}$ after the electrodialytic experiments is seen. For all the other metals, the water soluble amount was less than $1 \%$. The results show that the electrodialytic treatment reduced the water solubility of the metals, regardless of the final $\mathrm{pH}$ in the fly ash. This would not be expected as metal release in fly ash is usually highly $\mathrm{pH}$ dependent (Pedersen et al., 2005). However, this is a great advantage for potential reuse or local disposal of fly ash in Greenland. As the reduction of water solubility was so effective due to the electrodialytic treatment, shorter remediation times should be studied in the future. The reduced water solubility also means that the mobile parts of the metals were removed during the remediation, even though the total metal concentrations increased due to ash dissolution.

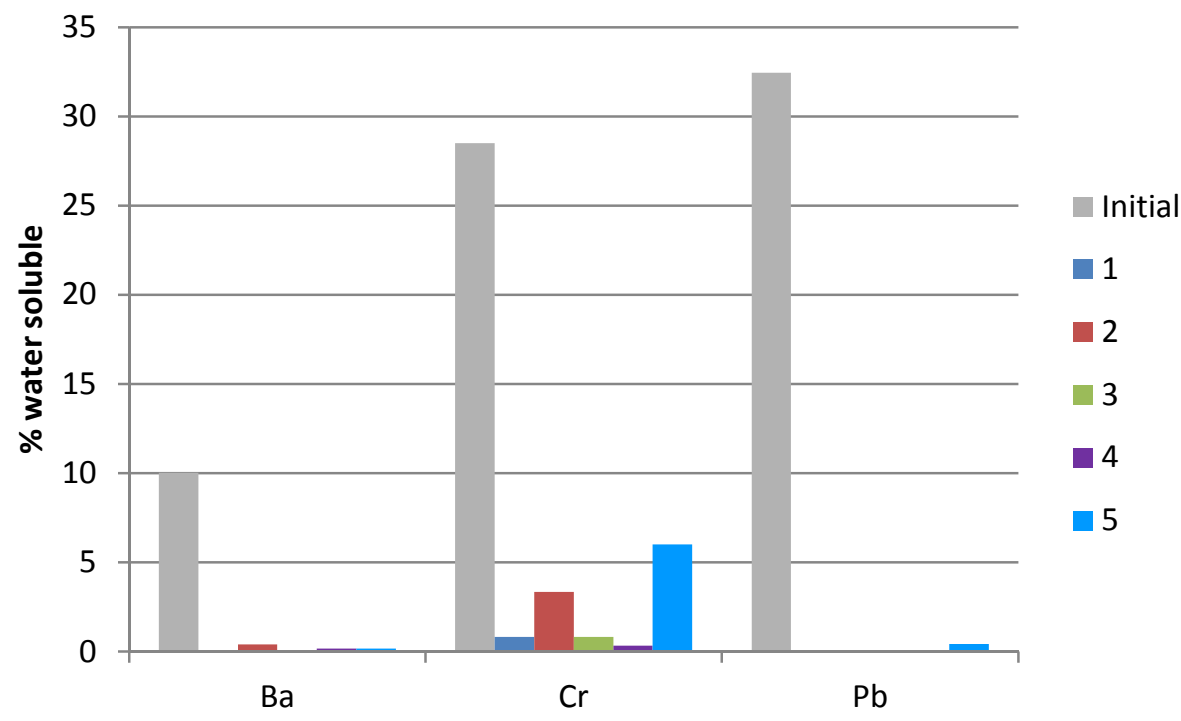

Figure 4: Water soluble metals after the electrodialytic remediation experiments

\section{CONCLUSION}

The electrodialytic remediation method showed potential as a treatment method for the Greenlandic fly ash. The metal solubility of the $\mathrm{Ba}, \mathrm{Cr}$ and $\mathrm{Pb}$ decreases after remediation compared to the initial solubility. The metal solubility of other measured metals is below $1 \%$ both before and after electrodialytic remediation. This shows that the acidification of the fly ash during the electrodialytic experiments does not mobilize the metals further. Thus, the fly ash is a less hazardous material than before the electrodialytic remediation. 
Depending on the desired end-use of the fly ash after remediation (disposal or reuse) different requirements to $\mathrm{pH}$ could be present, in either case; the solubility of metals in the electrodialytic treated fly ash is very low. To obtain high metal removal a low $\mathrm{pH}$ in the fly ash is necessary but this also leads to high dissolution of the fly ash.

\section{ACKNOWLEDGEMENTS}

The Greenlandic Grønlandsbankens Erhvervsfond is acknowledged for financing the study.

\section{REFERENCES}

Billen P., Uccello R. And Vandecasteele C., 2012. Cr (VI) formation and destruction during incineration of waste. Proceedings for the $4^{\text {th }}$ International Conference on Engineering for Waste and Biomass Valorisation, Porto, Portugal.

Cornelis G., Johnson A., Van Gerven T. and Vandecasteele C., 2008. Leaching mechanisms of oxyanionic metalloid and metal species in alkaline solid wastes: A review. Applied Geochemistry 23: 955-976.

Dansk Standardiseringsråd, 2003. Determination of metals in water, sludge and sediments - General guidelines for determination by atomic absorption spectrophotometry in flame. Danish Standard DS 259:2003.

Eighmy T.T., Eusden J.D. Krzarowski J.E. Domingo D.S., Stämpfli D., Martin J.R. and Erickson P.M., 1995. Comprehensive approach toward understanding element specification and leaching behavior in municipal solid waste incineration electrostatic precipitator ash. Environmental Science \& Technology 29: 629-646.

Eisted R. and Christensen T.H., 2011. Waste management in Greenland: Current situation and challenges. Waste Management \& Research. DOI: 10.1177/0734242X10395421

Gunnarsdottir R., Jørgensen M. W. and Villumsen A., 2008 Affaldshåndtering $i$ Grønland. Status på affaldshåndtering i 10 grønlandske kommuner. DTU Byg rapport R-190. September 2008. (In Danish)

Kirkelund G.M., Joergensen A.S., Ingeman-Nielsen T. and Villumsen A., 2012.

Characterisation of MSWI bottom ash for potential reuse as subbase in Greenlandic road construction. Proceedings for the $4^{\text {th }}$ International Conference on Engineering for Waste and Biomass Valorisation, Porto, Portugal.

Nystroem G.M., Ottosen L.M. and Villumsen A., 2005. Acidification of harbor sediment and removal of heavy metals induced by water splitting in electrodialytic remediation. Separation Science and Technology 40:2245-64. 
Ottosen L.M., Hansen H.K. and Hansen C.B., 2000. Water splitting at ion-exchange membranes and potential differences in soil during electrodialytic soil remediation. Journal of Applied Electrochemistry 30:1199-207.

Ottosen L.M., Lima A.T., Pedersen A.J. and Ribeiro A.B., 2006. Electrodialytic extraction of $\mathrm{Cu}, \mathrm{Pb}$ and $\mathrm{Cl}$ from municipal solid waste incineration fly ash suspended in water. Journal of Chemical Technology and Biotechnology 81: 553-559.

Pedersen A.J., Ottosen L.M. and Villumsen A., 2005. Electrodialytic removal of heavy metals from municipal solid waste incineration fly ash using ammonium citrate as assisting agent. Journal of Hazard Materials B122:103-9.

Quina, M.J., Bordado, J.C., Quinta-Ferreira, R.M., 2008. Treatment and use of air pollution control residues from MSW incineration: An overview. Waste Management 28 : 2097-2121.

Quina M., Bordado J.C.M. and Quinta-Ferreira R.M., 2011. Percolation and batch leaching tests to assess release of inorganic pollutants from municipal solid waste incinerator residues. Waste Management 31: 236-245. 